\title{
PECULIARITIES OF NON-ETHERIFIED FATTY ACIDS CONTENT IN CARP GILLS AT DIFFERENT CONCENTRATION OF COPPER AND ZINC IN THE WATER
}

\author{
Y. F. Rivis ${ }^{1}$, N. E. Yanovych ${ }^{2}$ \\ yandeni77@gmail.com
}

${ }^{1}$ Institute of Agriculture of Carpathian Region NAAS,

5 Grushevskogo str., Obroshino, Lviv Oblast, 81115, Ukraine

${ }^{2}$ Lviv National University of Veterinary Medicine and Biotechnologies named after S. Z. Gzhytsky,

50 Pekarska str., Lviv 79010, Ukraine

Copper and Zinc are essential for fishes elements with wide spectrum of biological activity; in particular, they are involved in regulation of fatty acids metabolism. Content and ratio of fatty acids in fish meat is directly influenced with its nutritive and biological value; besides, fatty acids composition of cells membranes determines their penetration for xenobiotics, including heavy metals. Thus, investigation of the influence of mentioned elements on the fatty acids metabolism in tissues of fishes has both theoretical and practical importance.

The experiment was conducted on three groups (10 fishes in each group) of two year old common carp (Cyprinus carpio L.). Carps were kept for 21 days without feeding in aquariums with different concentration of Copper and Zinc in the water - 0.3 and $4.2 \mathrm{mg} / \mathrm{l}$ correspondingly for control group, one maximum permitted level (1 MPL) for the $1^{\text {st }}$ experimental group and $2 M P L$ for the $2^{\text {nd }}$ experimental group. At the end of the experiment carps of each group were weighted, and samples of the gills were taken after slaughter for laboratory research. Concentration of copper and zinc in the gills was determined by spectrometric method, and concentration of non-etherified fatty acids was measured by gas chromatographic method.

Presented results shows that at 1 MPL of Zinc and Copper in the water, their concentration in carp gills increases by $9.31 \%(P<0.02-0.05)$ and $29.54 \%$ respectively in comparison to the fishes of the control group. At 2 MPL of Zinc and Copper in the water, Zinc increases in carp gills by $16.49 \%(P<0.01)$, and Copper increases by $104.54 \%(P<0.001)$ in comparison to the control group. Increasing of Copper and Zinc concentration in carp gills is accompanied by changes of the concentrations of non-etherified fatty acids in them. In particular, at 1 MPL of Copper and Zinc in the water, the increasing of total content of high metabolically active non-etherified fatty acids in carp gills was observed. At the same time, at 2 MPL of Copper and Zinc in the water, total content of high metabolically active non-etherified fatty acids in the gills of carps was decreased. Changes of Copper, Zinc and non-etherified fatty acids concentrations in the gills of carps were accompanied by changes of their live weight in the end of the experiment. Carps of the control group lost $3.90 \%$ of live weight, and carps of the $1^{\text {st }}$ and the $2^{\text {nd }}$ experimental groups -4.91 and $9.75 \%(P<0.02-0.05)$ respectively.

Keywords: NON-ETHERIFIED FATTY ACIDS, ZINC, COPPER, GILLS, CARP, LIVE WEIGHT

\section{ОСОБЛИВОСТІ ВМІСТУ НЕЕТЕРИФІКОВАНИХ ЖИРНИХ КИСЛОТ В ЗЯБРАХ КОРОПА ЗА РІЗНОЇ КОНЦЕНТРАЦІЇ МІДІ ТА ЦИНКУ У ВОДІ}

\author{
Й. Ф. Рівіс ${ }^{l}$, H. С. Янович ${ }^{2}$ \\ yandeni77@gmail.com
}

${ }^{1}$ Інститут сільського господарства Карпатського регіону НААН, вул. Грушевського, 5, с. Оброшино, Львівська обл., 81115, Україна

${ }^{2}$ Львівський національний університет ветеринарної медицини та біотехнологій імені С. 3. Гжицького,

вул. Пекарська, 50, м. Львів, 79010, Україна

Цинк та Мідь належать до життєво важливих для риб елементів з иироким спектром біологічної дї;; зокрема, вони впливають на проиеси обміну жсирних кислот. Вміст та співвідношення жирних кислот безпосередньо впливає на харчову та біологічну цінність м'яса риб, крім того, жирнокислотний склад клітинних мембран впливає на їхню проникність для ксенобіотиків, у тому числі важких металів. Таким чином, дослідження впливу вказаних елементів на метаболізм жирних кислот у різних органах і тканинах промислових риб має як теоретичне, так і практичне значення. 
Дослідження проводились на трьох групах дворічок коропа (Cyprinus carpio L.) по 10 особин у кожній групі. Коропи утримувались впродовж 21 дня без підгодівлі в умовах акваріуму з кониентрачією Міді та Цинку у воді, відповідно, 0,3 та 4,2 мг/л для контрольної групи, однієї гранично допустимої кониентрачії (1 ГДК) для I дослідної групи та 2 ГДК для II дослідної групи. Наприкінчі досліду коропів кожної групи зважували, зразки зябер після забою відбирали для лабораторних досліджень. Вміст Цинку та Midi в зябрах визначали спектрометричним методом, конщентрацію неетерифікованих жирних кислот визначали методом газової хроматографії.

Представлені результати досліджень свідчать, що за 1 ГДК Цинку і Міді у воді їхня концентрачія в зябрах коропа зростає, відповідно, на 9,31\% $(P<0,02-0.05)$ та 29,54\% порівняно з рибами контрольної групи. За 2 ГДК Цинку та Міді у воді концентрачія Цинку у зябрах коропа зростає на 16,49 \% $(P<0,01)$, a Midi - на 104,54\% (P<0,001) порівняно з контрольною групою. Збільшення концентрачії Цинку та Міді в зябрах коропа призводило до змін вмісту в них неетерифікованих жирних кислот. Зокрема, за 1 ГДК Цинку та Купруму у воді у зябрах коропа спостерігалось збільшення загального вмісту високо метаболічно активних неетерифікованих жирних кислот. Водночас за 2 ГДК Цинку та Купруму у воді загальний вміст високо метаболічно активних жирних кислот в зябрах коропа знижувався. Зміни концентрації Цинку, Купруму та неетерифікованих жирних кислот в зябрах коропа супроводжувались змінами їх живої ваги наприкінщі експерименту. Коропи контрольної групи втрачали 3,90\% \% маси тіла, а коропи I та II дослідних груп відповідно, 4,91 та 9,75\% $(P<0,02-0,05)$.

КЛючові слова: НЕЕТЕРИФІКОВАНІ ЖИРНІ КИСЛОТИ, ЦИНК, МІДЬ, ЗЯБРА, КОРОПИ, ЖИВА МАСА

\title{
ОСОБЕННОСТИ СОДЕРЖАНИЯ НЕЭСТЕРИФИЦИРОВАННЫХ ЖИРНЫХ КИСЛОТ В ЖАБРАХ КАРПА ПРИ РАЗЛИЧНОЙ КОНЦЕНТРАЦИИ МЕДИ И ЦИНКА В ВОДЕ
}

\author{
Й. Ф. Ривис ${ }^{1}$, Н. Е. Янович ${ }^{2}$ \\ yandeni77@gmail.com
}

${ }^{1}$ Институт сельского хозяйства Карпатського региона НААН, ул. Грушевского, 5, с. Оброшино, Львовская обл., 81115, Украина ${ }^{2}$ Львовский национальный университет ветеринарной медицины и биотехнологий имени С. З. Гжицкого, ул. Пекарская, 50, г. Львов, 79010, Украина

Медь и Цинк относятся к жизненно важным для рыб элементам с широким спектром биологического воздействия, одной из сторон которого является влияние на обмен жсирных кислот. Содержание и соотнотение жирных кислот в мясе рыб непосредственно влияет на его пищевую и биологическую иенность, кроме того, жирнокислотный состав клеточныхх мембран влияет на их проницаемость для ксенобиотиков, в том числе тяжельх металлов. Таким образом, исследование влияния указанных элементов на метаболизм жирных кислот в различных органах и тканях промышленных рыб имеет как теоретическое, так и практическое значение.

Исследования проводились на трех группах двухлеток карпа (Cурrinus carpio L.) по 10 особей в каждой группе. Карпы содержались на протяжении 21 дня без кормления в условиях аквариума с концентраиией Меди и Цинка в воде, соответственно, 0,3 и 4,2 мг/л для контрольной группы, одной предельно допустимой конщентраџией (1 ПДК) для I экспериментальной группы и 2 ПДК для II экспериментальной группы. В конце опыта карпов каждой из групп взвешивали, образиы жабр послы забоя отбирали для лабораторных исследований. Содержание Цинка и Меди в жабрах определяли спектрометрическим методом, концентрачию неетерифицированных жирных кислот - методом газовой хроматографии.

Представленные результаты свидетельствуют, что при 1 ПДК Цинка и Меди в воде их концентрация в жабрах увеличивается на 9,31\% $(P<0,02-0,05)$ и 29,54\% в сравнении с рыбами контрольной группь. При 2 ПДК Цинка и Меди в воде концентрачия Цинка в жабрах карпа увеличивается на 16,94\% $(P<0,01)$, а Меди - на 104,54\% (P<0,001) в сравнении с контрольной группой. Повыпение концентраџии Меди и Цинка в жабрах карпа приводило кизменению содержсния в них неэстерифицированных жирных кислот. При 1 ПДК Цинка и Меди в воде в жабрах карпа наблюдалось увеличение общего содержания высоко метаболически активных неэстерифицированных жирных кислот. Одновременно, при 2 ПДК Меди и Цинка в воде общее содержание высоко метаболически активных жирных кислот в жабрах карпа понижалось. Изменения концентрации Меди, Цинка и неэстерифицированных жирных кислот в жабрах карпа 
сопровождалось изменениями массы их тела в конце эксперимента. Карпы контрольной группь теряли 3,90\% живой массы, а карпы I и II экспериментальных групп - соответственно, 4,91 и 9,75\% (P<0,02-0,05).

КлючевЫе слова: НЕЭСТЕРИФИЦИРОВАННЫЕ ЖИРНЫЕ КИСЛОТЫ, ЦИНК, МЕДЬ, ЖАБРЫ, КАРПЫ, ЖИВАЯ МАССА

Metabolic processes in freshwater fishes are greatly affected by trace elements [7,23]. Trace elements influence on different pathways of the metabolic processes is depended on number of factors, mainly on their concentration in the water [10, 16]. Deficiency of trace elements may lead to disorders of vitally important functions, delay of growth and development, anemia, oxidation stress etc. At the same time, the excessive content of trace elements may cause biochemical, structural and functional pathologies [7, 23]. Excessive concentration of mineral elements in aquatic ecosystems is considered to be an important ecological problem [7]; mostly it is caused by industrial and agricultural loading in the area or by local abnormally high native trace element content in the soil and crust.

Copper and Zinc are affecting metabolic processes in the freshwater fishes $[2,13,16]$ mainly as constituents of numerous enzymes [23]. For instance, Zinc is involved in the antioxidant system functioning as a part of the superoxide dismutase enzyme and in the regulation of fatty acids metabolism as a constituent of $\Delta^{3-}, \Delta^{4}, \Delta^{5-}$ and $\Delta^{6-}$ desaturases $[8,14,23]$. Copper influences the activity of antioxidant enzymes superoxide dismutase and, indirectly, catalase; besides, it affects the activity of $\Delta^{9-}$ desaturase $[5,19]$. Abovementioned desaturases are involved in fatty acids metabolism in fish's body. Thus, from the one hand, both Zinc and Copper are regulated antioxidant system activity and processes of fatty acids desaturation; from the other hand, antagonistic interaction between these two elements, for example, for binding sites in proteins molecules, is reported [20]. Moreover, regardless numerous investigations of lipids and fatty acids metabolism in fish $[6,11]$, its tissue specificity under influence of Zinc and Copper is not clarified yet. According to this, the aim of our experiment was to research the peculiarities of non-etherified fatty acids content of carp gills at normal and over threshold levels of Copper and Zinc in the water. This experiment is a part of investigation of fatty acids metabolism in carp body under influence of Zinc and Copper, some results of which were published before [21, 22].

\section{Materials and methods}

The experiment was conducted on three groups (10 fishes in each group) of two year old common carp (Cyprinus carpio L.) with average live weight $320 \mathrm{~g}$. For 21 days carps were kept without feeding in aquariums. Carps of the control group were kept in the water without Copper and Zinc addition (with Copper and Zinc concentration 0.3 and $4.2 \mathrm{mg} / \mathrm{l}$ correspondingly). Carps of the $1^{\text {st }}$ and the $2^{\text {nd }}$ experimental groups were kept in the water with addition of sulfates of Copper and Zinc. Concentration of Copper and Zinc in the aquarium water for the $1^{\text {st }}$ experimental group achieved $1 \mathrm{MPL}$ ( 1 and $10 \mathrm{mg} / 1$ correspondingly [17]), while for the $2^{\text {nd }}$ experimental group it achieved 2 MPL ( 2 and $20 \mathrm{mg} / 1$ correspondingly). Oxygen concentration in the aquariums water was maintained in the scope $7.0-8.0 \mathrm{mg} / 1$, carbon dioxide $-2.1-2.7 \mathrm{mg} / \mathrm{l}$. Water $\mathrm{pH}$ reached 7.6-7.9, temperature varied from 18 to $20^{\circ} \mathrm{C}$. Water in the aquariums of all experimental groups was changed every two days with the renewing of Copper and Zinc content.

In the end of experiment carps of each group were weighted and slaughtered via destruction of the brain by striking of the cranium [1]. Samples of the gills were taken for laboratory research. In mentioned tissues samples concentration of Copper, Zinc and non-esterified fatty acids were estimated.

Concentration of copper and zinc in gills was determined by spectrometric method [12]. Concentration of non-esterified fatty acids was determined by gas chromatographic method [15]. Lipids from the gills tissue were extracted by chloroform-methanol solvent (2:1).

Results of investigations were processed mathematically. Average magnitude (M), average error $( \pm \mathrm{m})$ and probability of differences between two 
average magnitudes $(\mathrm{P})$ were calculated. Difference between two average magnitudes was considered probable at $\mathrm{P}<0.05$. For calculations the programs Origin 6.0, Excel (Microsoft, USA) were used.

\section{Results and discussion}

It was revealed that at Zinc and Copper concentration in the water equated to $1 \mathrm{MPL}$, Zinc and Copper concentration in carp gills increases by $9.31 \%(\mathrm{P}<0.05)$ and $29.54 \%$ respectively in comparison to the fishes of the control group with native content of this elements in the water. At 2 MPL of Zinc and Copper in the water, Zinc increases in carp gills by $16.49 \%(\mathrm{P}<0.01)$, and Copper - by $104.54 \%(\mathrm{P}<0.001)$ in comparison to the control group. The fact of accumulation of Zinc and Copper in gills at their high concentration in the water is also confirmed by number of studies [7].

Due both to broad spectrum of biological activity in fish body, and to the risk of their excessive income into water ecosystems, influence of Zinc and Copper on fish metabolic processes is widely researched. For example, influence of different concentration of Zinc and Copper on protein synthesis [4], amino acids metabolism [9], haematological and biochemical parameters [3] and lipids composition of fish tissues [11] were studied. At the same time, the elements influence on fatty acids metabolism in carp tissues is much less investigated.

Presented results shows that increasing of Copper and Zinc concentration in carp gills was accompanied by changes of the concentrations of non-etherified fatty acids in them (table 2), that pointed on the influence of relatively high concentrations of Copper and Zinc on free fatty acids metabolism. In particular, at 1 MPL of Zinc and Copper in the water, the tendency to increasing of total content of highly metabolically active non-etherified fatty acids in carp gills in comparison to control group is observed (table 2). The table shows, that the tendency to increasing of non-etherified fatty acids content in the gills is determined by saturated, monounsaturated and polyunsaturated fatty acids. In particular, in the gills of carps of experimental groups in comparison to the carps of control group, higher concentration of saturated fatty acids with even (201.6 mg/kg against $197.1 \mathrm{mg} / \mathrm{kg}$ of fresh weight) and odd (1.0 against $0.9 \mathrm{mg} / \mathrm{kg}$ of fresh weight) number of Carbon atoms in chain was detected, as well as concentration of monounsaturated fatty acids of $\omega-7$ (9.4 against 9.0) and $\omega-9$ family (630.8 against 624.4) and polyunsaturated fatty acids of $\omega-3$ (307.6 against 299.1) and $\omega-6$ family (315.3 against $304.5 \mathrm{mg} / \mathrm{kg}$ of fresh weight). Wherein, the ratio of non-etherified polyunsaturated fatty acids of $\omega-3$ family to $\omega-6$ family didn't change (table 2).

At 2 MPL of Zinc and Copper in the water, in the gills of experimental carps in comparison to the carps of control group, total content of high metabolically active non-etherified fatty acids was lower due to saturated, monounsaturated and polyunsaturated fatty acids (table 2). Decreasing of total content of non-etherified fatty acids in the gills of experimental carps was caused by lower concentration in their composition of saturated fatty acids with even (175.2 against $197.1 \mathrm{mg} / \mathrm{kg}$ of fresh weight) and odd (0.8 against 0.9 ) number of Carbon atoms in the chain, as well as lower concentration of monounsaturated fatty acids of $\omega-7$ (8.1 against 9.0) and $\omega-9$ family (572.4 against 624.4) and polyunsaturated fatty acids of $\omega-3$ (267.5 against 299.1) and $\omega-6$ family (263.1 against $304.5 \mathrm{mg} / \mathrm{kg}$ of fresh weight). Simultaneously, the increasing of the efficiency of transformation of non-etherified linoleic acid to its longer and more unsaturated derivatives ( 0.86 against 0.89) was established.

Table 2 presents, that at 2 MPL of Zinc and Copper in the water, in the gills of carps, in comparison to the carps of the control group, the lower concentration of non-etherified saturated fatty acids (myristic, palmitic, stearic and arachidic), monounsaturated fatty acid (palmitoleic) and polyunsaturated fatty acids (linolenic, eicosatrienoic, eicosapentaenoic, docosatrienoic, docosapentaenoic, docosahexaenoic) was revealed $(\mathrm{P}<0.02-0.05)$.

Changes of Copper, Zinc and non-etherified fatty acids concentrations in the gills of carps are accompanied by changes of their live weight in the end of the experiment (table 3). For instance, during the experiment, carps of the control group lost $3.90 \%$ of live weight, and carps of the $1^{\text {st }}$ and the $2^{\text {nd }}$ experimental groups -4.91 and $9.75 \%$ $(\mathrm{P}<0.02-0.05)$ respectively. 


\section{Copper and Zinc concentration in carp gills under their different content in the aquarium water, $\mathrm{mg} / \mathrm{kg}$ of fresh weight, $M \pm m, n=10$}

\begin{tabular}{|c|c|c|}
\hline Control group & $\begin{array}{c}\text { The } 1^{\text {st }} \text { Experimental group } \\
\text { (1 MPL of Zinc and Copper in the water) }\end{array}$ & $\begin{array}{c}\text { The 2 } 2^{\text {nd }} \text { Experimental group } \\
\text { (2 MPL of Zinc and Copper in the water })\end{array}$ \\
\hline \multicolumn{3}{|c|}{ Concentration of Zinc in the gills } \\
\hline $247.47 \pm 6.253$ & $270.53 \pm 4.765^{*}$ & $288.30 \pm 4.708^{* *}$ \\
\hline \multicolumn{3}{|c|}{ Concentration of Copper in the gills } \\
\hline $0.88 \pm 0.037$ & $1.14 \pm 0.090$ & $1.80 \pm 0.101^{* * *}$ \\
\hline
\end{tabular}

Note: here and further * $-\mathrm{P}<0.02-0.05 ; * *-\mathrm{P}<0.01$; *** $-\mathrm{P}<0.001$.

\section{Non-esterified fatty acids content in gills of carps under different concentration} of Copper and Zinc in the aquarium water, $\mathrm{mg} / \mathrm{kg}$ of fresh weight, $M \pm m, n=10$

\begin{tabular}{|l|c|c|c|}
\hline $\begin{array}{c}\text { Non-esterified fatty acids } \\
\text { and their abbreviation }\end{array}$ & Control group & $\begin{array}{c}\text { The 1st Experimental group } \\
\text { (1 MPL of Copper and Zinc } \\
\text { in the water })\end{array}$ & $\begin{array}{c}\text { The 2nd Experimental group } \\
(2 \text { MPL of Copper and Zinc } \\
\text { in the water })\end{array}$ \\
\hline Capric acid, 10:0 & $0.3 \pm 0.03$ & $0.33 \pm 0.033$ & $0.17 \pm 0.033$ \\
\hline Lauric acid, 12:0 & $0.6 \pm 0.06$ & $0.63 \pm 0.033$ & $0.50 \pm 0.057$ \\
\hline Myristic acid, 14:0 & $4.8 \pm 0.20$ & $4.9 \pm 0.29$ & $4.10 \pm 0.17^{*}$ \\
\hline Pentadecanoic acid, 15:0 & $0.9 \pm 0.03$ & $0.97 \pm 0.033$ & $0.77 \pm 0.033$ \\
\hline Palmitic acid, 16:0 & $92.0 \pm 2.42$ & $94.6 \pm 2.71$ & $83.3 \pm 1.65^{*}$ \\
\hline Palmitoleic acid, 16:1 & $9.0 \pm 0.20$ & $9.4 \pm 0.18$ & $8.1 \pm 0.17^{*}$ \\
\hline Stearic acid, 18:0 & $24.7 \pm 1.33$ & $25.9 \pm 1.36$ & $19.4 \pm 0.90^{*}$ \\
\hline Oleic acid, 18:1 & $529.9 \pm 13.26$ & $535.4 \pm 13.19$ & $486.1 \pm 11.18$ \\
\hline Linoleic acid, 18:2 & $143.5 \pm 7.13$ & $149.8 \pm 7.31$ & $122.0 \pm 4.69$ \\
\hline Linolenic acid, 18:3 & $81.2 \pm 1.96$ & $83.8 \pm 1.81$ & $73.7 \pm 1.41^{*}$ \\
\hline Arachidic acid, 20:0 & $74.6 \pm 1.74$ & $75.2 \pm 1.62$ & $67.7 \pm 1.56^{*}$ \\
\hline Eicosenic acid, 20:1 & $94.5 \pm 2.28$ & $95.4 \pm 2.37$ & $86.3 \pm 1.90$ \\
\hline Eicosadienoic acid, 20:2 & $58.5 \pm 2.20$ & $59.3 \pm 2.20$ & $52.2 \pm 1.07$ \\
\hline Eicosatrienoic acid, 20:3 & $30.5 \pm 1.21$ & $31.5 \pm 1.28$ & $25.6 \pm 1.27^{*}$ \\
\hline Eicosatetraenoic (arachidonic) acid, 20:4 & $40.2 \pm 1.62$ & $41.2 \pm 1.70$ & $35.3 \pm 1.04$ \\
\hline Eicosapentaenoic acid, 20:5 & $58.5 \pm 1.59$ & $59.2 \pm 1.70$ & $51.7 \pm 1.76^{*}$ \\
\hline Docosadienoic acid, 22:2 & $10.4 \pm 0.49$ & $11.0 \pm 0.61$ & $8.9 \pm 0.26$ \\
\hline Docosatrienoic acid, 22:3 & $21.6 \pm 0.52$ & $22.2 \pm 0.46$ & $19.3 \pm 0.52^{*}$ \\
\hline Docosatetraenoic acid, 22:4 & $21.5 \pm 0.67$ & $22.4 \pm 0.55$ & $19.2 \pm 0.49$ \\
\hline Docosapentaenoic acid, 22:5 & $46.2 \pm 1.41$ & $47.7 \pm 1.50$ & $40.3 \pm 1.33^{*}$ \\
\hline Docosahexaenoic acid, 22:6 & $91.6 \pm 2.28$ & $84.7 \pm 10.03$ & $82.5 \pm 2.20^{*}$ \\
\hline Total content of fatty acids & 1435.0 & 1465.6 & 1287.1 \\
\hline Including saturated & 197.9 & 202.5 & 176.0 \\
\hline monounsaturated & 633.4 & 640.2 & 580.5 \\
\hline polyunsaturated & 603.6 & 622.9 & 530.6 \\
\hline$\omega-3 / \omega-6$ & 0.98 & 0.98 & 1.02 \\
\hline
\end{tabular}

Live weight of two year old carp under different concentration of Copper and Zinc in the aquarium water, $\mathrm{g}, \mathbf{M} \pm \mathbf{m}, \mathbf{n}=\mathbf{1 0}$

\begin{tabular}{|c|c|c|}
\hline Control group & $\begin{array}{c}\text { The } 1^{\text {st }} \text { Experimental group } \\
\text { (1 MPL of Zinc and Copper in the water) }\end{array}$ & $\begin{array}{c}\text { The } 2^{\text {nd }} \text { Experimental group } \\
\text { (2 MPL of Zinc and Copper in the water) }\end{array}$ \\
\hline \multicolumn{3}{|c|}{ In the beginning of the experiment } \\
\hline $320.3 \pm 5.72$ & $320.0 \pm 6.18$ & $320.0 \pm 5.67$ \\
\hline $307.8 \pm 5.57$ & In the end of the experiment (45 days) \\
\hline \multicolumn{3}{|c|}{$304.3 \pm 5.87$} \\
\hline
\end{tabular}




\section{Conclusions}

In our previous experiments we have studied Zinc and Copper influence on fatty acids metabolism in skeletal muscles and liver of carp. Present paper shows, that at increasing of Zinc and Copper concentration in the water, the elements are accumulated in gills tissue in different measures; that can be explained by different capability of metallothioneins to bind these metals.

At 1 MPL of Copper and Zinc in the water, the increasing of total content of high metabolically active non-etherified fatty acids in carp gills was observed. Higher concentration of saturated fatty acids with even and odd number of Carbon atoms in chain was detected, as well as concentration of monounsaturated fatty acids of $\omega-7$ and $\omega-9$ family and polyunsaturated fatty acids of $\omega-3$ and $\omega-6$ family. At 2 MPL of Copper and Zinc in the water, total content of high metabolically active nonetherified fatty acids in carp gills was lower due to saturated, monounsaturated and polyunsaturated fatty acids. Decreasing of non-etherified fatty acids of $\omega-3$ family to non-etherified fatty acids of $\omega-6$ family ratio was observed.

Increasing of Zinc and Copper and changes of non-etherified fatty acids concentrations in the gills of carps were accompanied by loss of their body weight in the end of the experiment; mentioned changes were probable for $2^{\text {nd }}$ experimental group.

Perspectives for further research. Presented results are the part of complex investigation, dedicated to research of Copper and Zinc influence at different concentrations on different metabolic pathways in common carp.

1. Appendix A of the European convention for the protection of vertebrate animals used for experimental and other scientific purposes (Ets no. 123). Guidelines for accommodation and care of animals (Article 5 of the Convention) approved by the multilateral consultation. Strasbourg, 15 June 2006, 109 p.

2. Clearwater S. J., Farag A. M., Meyer J. S. Bioavailability and toxicity of diet borne Copper and Zinc to fish. Comp. Biochem. Physiol. C. Toxicol. Pharmacol., 2002, vol. 132, no. 3, pp. 269-313.

3. Dhanapakiam P. Toxic effects of copper and zinc mixtures on some haematological and biochemical parameters in common carp, Cyprinus carpio (linn). J. Environ. Biol., 2001, vol. 22, pp. 105-111.
4. Evtushenko N. Y., Malugeva T. D. Intensity of protein synthesis in carp liver at keeping in water with different zinc concentration. Theses of report of Second Union Conference on the use of warm waters of TPS and APS for fisheries purposes, Moscow, 1980, pp. 26-27. (in Russian)

5. Hongxia J., Hongmei Y., Xianghui K., Shuping W. Huiyun G. Changes of superoxide dismutase and catalase activities in crucian carp (Carassius auratus) exposed to copper and recovery response. Life Sci. J., 2013, 10 (1), pp. 3281-3288.

6. Hrytsyniak I.I.,Smolyaninov K. B., Yanovych V.G. Lipids metabolism in fish. Lviv, Triada plus, 2010, 336 p. (in Ukrainian)

7. Hrytsyniak I. I., Yanovych D. O., Schvets T. M. Ecotoxicology of Salmonids. Kyiv, Ltd. "DIA", 2015, 472 p. (in Ukrainian)

8. Huang Y. S., Cunnane S. C., Horrobin D. F., Davignon J. Most biological effects of Zinc deficiency corrected by gamma-linolenic acid (18:3 omega 6$)$ but not by linoleic acid (18:2 omega 6). Atherosclerosis, 1982, 41, pp. 193-207.

9. Kurant V. Z., Brodin S. V., Syniuk Y. V. The influence of heavy metals on glycine metabolism in tissues of carp (Cyprinus carpio L.). Materials of Metals and Cell Symposium Canterbury, University of Kent at Canterbury, 2001, $45 \mathrm{p}$.

10. Kurant V. Z., Chomenchuk V. O., Bujak V. Y. Ways of penetration and content of heavy metals in fish body. A review. Scientific Notes of Ternopil National Pedagogical University named after Volodymyr Hnatiuk, Series Biology, 2011, vol. 2 (47), pp. 263269. (in Ukrainian)

11. Manyora G. B., Grubinko V. V. Dynamics of lipid composition of fish brain at intoxication of heavy metals ions. Hudrobiological J., 2004, vol. 40, no. 5, pp. 49-56. (in Russian)

12. Price W. J. Analytical Atomic Absorption Spectrometry. Heyden and Son Ltd., London, 1972, 239 p.

13. Rajamanickam V., Muthuswamy N. Effect of heavy metals induced toxicity on metabolic biomarkers in common carp (Cyprinus carpio L.). $M$ j. Int. J. Sci. Tech., 2008, 12 (01), pp. 192-200.

14. Reed S., Xia Qin, Ran-Ressler R., Brenna J.-T., Glahn R. P., Tako E. Dietary Zinc deficiency affects blood linoleic acid: dihomo- $\gamma$-linolenic acid (LA:DGLA) ratio; a sensitive physiological marker of Zinc status in vivo (Gallus gallus). Nutrients, 2014, 6(3), pp. 1164-1180.

15. Rivis J. F., Fedoruk R. S. Quantitative and qualitative chromatographical methods of some lipids and fatty acids determination in biological material. Lviv, Spolom, 2010, 110 p. (in Ukrainian)

16. Sandor Z.,Csengeri I.,Oncsik M.B.,Alexis M.N., Zubcova E. Trace metal levels in freshwater fish, sediment and water. Environ. Sci. Pollut. Res. Int., 2001, 8 (4), pp. 265-268.

17. Standards of water quality for facilities for fisheries purposes, including standards of maximum 
permitted levels of harmful substances in water of facilities for fisheries purposes. Moscow, VNIRO, 2011, 257 p. (in Russian)

18. Štrbac S., Kašanin-Grubin M., Jovančićević B., Simonović P. Bioaccumulation of Heavy Metals and Microelements in Silver Bream (Brama brama L.), Northern Pike (Esox lucius L.), Sterlet (Acipenser ruthenus L.), and Common Carp (Cyprinus carpio L.) From Tisza River, Serbia. J. Toxicol. Environ. Health A., 2015, 78 (11), pp. 663-665.

19. Wahle K. W. J., Davies N. T. Effect of dietary Copper deficiency in the rat on fatty acid composition of adipose tissue and desaturase activity of liver microsomes. British Journal of Nutrition, 1975, 34, pp. 105-112.
20. Watanabe T., Kiron V., Satoh H. Trace minerals in fish nutrition. Aquaculture, 1997, 151, pp. 185-207.

21. Yanovych N. E. Fatty acids composition of carp skeletal muscles under influence of different copper and zinc concentration in water. Fisheries Science of Ukraine, 2013, vol. 2, pp. 70-75.

22. Yanovych N. E. Influence of different copper and zinc concentration in water on fatty acids composition of carp liver. Fisheries Science of Ukraine, 2013, vol. 1, pp. 50-57.

23. Yanovych N. E., Yanovych D. O. Role of trace elements in pond fishes vital functions. Science herald of LNUVM and BT named after S. Z. Gzhytsky, 2014, vol. 16 , no. 2 , pp. 345-372. (in Ukrainian) 